\title{
Edom versus Edom
}

\section{Echoes of the Lutheran Reformation in Early Modern Jewish Writings}

Five hundred years have passed since Martin Luther stepped out publicly with his Ninety-five Theses and launched the Reformation. ${ }^{1}$ This move carried farreaching consequences not only within Christian circles but also for European Jewry. It was only natural that the Jews of the period evinced a "great interest in Luther, who seemed to wield the shovel digging the grave of Christianity's burial"2 Jewish authors were interested in the Protestant Reformation, in the person and teachings of Martin Luther, and in the theological schism within Christendom as well. Unsurprisingly, they judged the religious struggle between the new sect and the Catholic Church from their own frame of reference and no single 'Jewish' view manifested itself, but a variety of perspectives selectively favoring different groups and religious doctrines instead emerged.

This topic has rather escaped scholarly attention. Some important exceptions include Hillel Ben-Sasson's study from half a century ago, ${ }^{3}$ several articles by Jerome Friedman ${ }^{4}$ and Abraham David, ${ }^{5}$ and few monographs focusing on particular cases of Jewish-Christian encounters during the Reformation period. ${ }^{6}$

1 It is perhaps an oversimplification to use the term 'Reformation' in singular as most scholars agree that no unified reformatory movement existed but rather a variety of 'reformations' of which the appearance of Martin Luther was neither the first nor the last. Jewish authors commenting on activities of Martin Luther and his followers were well aware of such diversity, as it will be shown further.

2 Jerome Friedman, “The Reformation in Alien Eyes: Jewish Perception of Christian Troubles," The Sixteenth Century Journal 14 (1983): 23-40, here 26.

3 Haim Hillel Ben-Sasson, "The Reformation in Contemporary Jewish Eyes," The Israel Academy of Sciences and Humanities Proceedings, vol. 4, 12 (1970). Of the same author see also "Jewish-Christian Disputation in the Setting of Humanism and Reformation in the German Empire," Harvard Theological Review 59 (1966): 369-90.

4 Friedman, "The Reformation in Alien Eyes," and also idem, "The Reformation and Jewish Antichristian Polemics,” Bibliotheque d'Humanisme et Renaissance 41, 1 (1979): 83-97.

5 Abraham David, "The Lutheran Reformation in Sixteenth-Century Jewish Historiography," Jewish Studies Quarterly 10 (2003): 124-39.

6 Hava Fraenkel-Goldschmidt, The Historical Writings of Joseph of Rosheim in Early Modern Germany (Leiden: Brill, 2006); Debra Kaplan, Beyond Expulsion: Jews, Christians, and Reformation Strasbourgh (Stanford, CA: Stanford University Press, 2011); Selma Stern, Josel of Rosheim: Commander of Jewry in the Holy Roman Empire of the German Nation, trans. Gertrude Hirschler (Philadelphia: Jewish Publication Society of America, 1965).

Ә OpenAccess. (c) 2020 Aue-Ben-David et al., published by De Gruyter. (cc))BY This work is licensed under the Creative Commons Attribution 4.0 International. https://doi.org/10.1515/9783110664713-004 
The present article aims to expand the discussion by presenting a wide scope of Jewish reactions to the developments in Christian society and theology that took place in sixteenth-century Europe. The corpus of examined sources ranges from stark descriptive accounts to more elaborate reflections of theological innovations to texts that used major themes of the Lutheran Reformation in highly creative ways. Jewish authors recognized the doctrinal conflict as well as the social and political ramifications of the reform within Western Christendom, and some incorporated insight from the Reformation into Jewish apocalyptic writings of the sixteenth century.

One may classify the Hebrew sources dealing with the Reformation by temporal and physical provenance. Sources contemporaneous with Luther were mostly descriptive attempts to characterize the new face of Christianity. Jews perceived the breakup of the monolithic Catholic framework as auguring better relations between Jews and Christians in the future. The reformer's appearance and his initial call to abandon traditional Christian hostility towards $\mathrm{Jews}^{7}$ aroused a twofold reaction among Jews. On the one hand, it bolstered their hopes for a new, more tolerant world order; on the other, the idea that the great Catholic Church was not impregnable afforded them significant satisfaction.

Sources originating in Germany and its environs, where Jews encountered Protestantism first-hand, expressed different opinions about Luther than, for example, Italian ones, whose authors were acquainted with the papacy. And both groups of writings differed from texts written by authors living in the Polish-Lithuanian Commonwealth, which at that time enjoyed extraordinary religious tolerance, and in the Ottoman Empire, whose Jewish inhabitants had to rely on hearsay for news of the Reformation's effects. A double-edged wordplay on Luther's name gives us a glimpse of this variation in viewpoint: Joseph (Josel) of Rosheim (c. 1478-1554), Eliezer Eilburg (c. 1530 - c. 1580) and other Jews living in the German area referred to Luther in Hebrew as "lo-tahor" (impure), while Jewish authors beyond the reach of Luther's activity referred to him as "Lauter" German word for "pure." In the kabbalistic writings of Abraham ben Eliezer Ha-Levi (1460 -1528), we even find the following tribute: "For this man who is called Martin Luther has done away with idolatry, may he and his portion be blessed."

7 Though, philosemitic hints of early Luther, expressed in That Jesus Christ Was Born a Jew (1523), were directed solely at fostering conversion, and intended primarily as a polemic against Catholicism. See e.g. Thomas Kaufmann, Luther's Jews: A Journey into Anti-Semitism, trans. Lesley Sharpe and Jeremy Noakes (Oxford: Oxford University Press, 2017), esp. 54-75.

8 From a letter of Abraham ben Eliezer Ha-Levi, see Ira Robinson, "Two Letters of Abraham Eliezer Halevi," in Studies in Medieval Jewish History and Literature (vol. II), ed. Isadore Twer- 
Additionally, one can identify various genres among the Jewish texts under discussion. Many, of course, are chronicles, as follows from the nature of the narrative genre. ${ }^{9}$ Nonetheless, one encounters passages mentioning Luther and Lutheranism in other types of literature as well, such as polemical treatises and prophetic writings.

In his chronicle Chain of Tradition (Šalšelet ha-kabalah), Gedaliah Ibn Yahya (c. 1526-1587) refers to the event of 1517 in rather terse terms: "In the year 1449 to the destruction of the Second Temple Martin Luther began to express his arguments."10 Other early modern Jewish historiographers, however, offer less succinct reports. David Gans (c. 1541-1592), for example, wrote in the second volume of his Sprout of David (Tsemach David), with respect to the year when the Diet of Worms took place:

Martin Luther, a great scholar and expert in Christian books, studied scrupulously and examined and created a lot of writings, following Johannes Huss who was mentioned above to year 5174/1413. He stood up against the pope and divided the hearts of Christians. He told them to burn all images and statues and no longer offer their prayers to Miriam, mother of their Messiah, and to the Twelve Apostles, and [instructed] bishops, priests and nuns to get married, and [introduced] many other novelties. A lot of people agreed with him immediately and with him lined up the most important princes and burghers in Germany, namely the dukes of Saxony, Silesia, Hessen, Mecklenburg, Brandenburg, Pomerania, Baden, from Switzerland and from Austrian towns, from [Augsburg], Ulm, Nuremberg, Frankfurt, Basel, Strasbourg and many others.

His teaching was made public at the Diet of Worms in 5282, 1522 according to the Christian calendar, and then great wars broke up in a majority of European lands, greater and heavier year by year, and so more than thousands of thousands Christians perished and were killed for his teaching up to our present time. ${ }^{11}$

First and foremost, we notice that Gans was able to identify Luther, whom he esteemed as a well-read scholar and prolific author in Christian doctrine, ${ }^{12}$ as

sky (Cambridge: Harvard University Press, 1984), 412; and Gershom Scholem, "Perakim me-toldot ha-kabalah," Kiryat Sefer 7 (1930-1931): 446.

9 On Jewish attitudes towards historiography, see Robert Bonfil, "Jewish Attitude toward History and Historical Writing in Pre-Modern Times," Jewish History 11, 1 (1997): 7-40; and "How Golden Was the Age of Renaissance in Jewish Historiography?" History and Theory 27, 4 (1988): 78-102. The already mentioned article by Abraham David also discussed in particular historiographic writings mentioning Luther; see David, "The Lutheran Reformation."

10 Gedaliah Ibn Yahya, Šalšelet ha-kabalah (Venice: Giovanni di Gara, 1587), 116v.

11 David Gans, Tsemach David (Prague: 1592), vol. II, 103v.

12 Also Joseph of Rosheim acknowledged that Luther "wrote many books," yet these were "books of heresy [that] used to fall out of his lap"; Fraenkel-Goldschmidt, The Historical Writings, 301. 
a follower of an earlier reform movement, namely, that of Jan Hus (1369-1415). Hus, after whom the eponymous Hussite movement was named, was a priest active in late medieval Prague. A well-known representative of the Bohemian Reformation, Hus preached against indulgencies, a theme of acute interest in Luther's Ninety-five Theses. Gans' mention of Hus was highly related to his place of residence; the Utraquists had a strong presence in Rudolfine Prague. ${ }^{13}$

Furthermore, David Gans acknowledged the impact of Luther's appearance in the religious strife and highlighted some of its relevant points characterizing the theological conflict between the Catholics and the Reformed. After mentioning Luther's rejection of papal authority, Gans noted the movement's fierce iconoclasm. This negative stance towards images and the veneration of saints was, to a greater or lesser degree, shared by all reformers; ${ }^{14}$ moreover, it was easy to observe its actual manifestations in Protestant towns. Other Jewish authors writing about Luther and Christian Reformation also mentioned iconoclastic riots. Abraham ben Eliezer Ha-Levi, ${ }^{15}$ whose knowledge of the European religious conflict must have been only indirect, wrote that: "Protestants destroy and burn images of their gods and their idols are cut down in all parts of his [Luther's] dominion," ${ }^{16}$ and similarly, Joseph ben Joshua Ha-Kohen (1496-1575) states in the History of Kings of France and Ottoman (Divrey ha-yamim le-malkhei Zarfat u-veyt Ottoman ha-Tugar): ${ }^{17}$ "No longer were graven images set up or homage paid to

13 During the reign of Rudolf II Habsburg (1552-1612), Prague represented one of the leading centres of the arts and sciences in Europe, and a religiously tolerant milieu, guranteed by the Czech Confession and the Majestätsbrief. Eliska Fucíková, Prague in the Reign of Rudolph II (Prague: Karolinum, 2015).

14 See e.g. Carlos M. N. Eire, War against Idols: The Reformation of Worship from Erasmus to Calvin (Cambridge: Cambridge University Press, 1986); Willem Van Asselt, "The Prohibition of Images and Protestant Identity," in Iconoclasm and Iconoclash: Struggle for Religious Identity, eds. Willem Van Asselt, Paul van Geest, Daniela Mueller and Theo Salemink (Leiden and Boston: Brill, 2007), 299-311.

15 On Abraham ben Eliezer Ha-Levi and his works, see Abraham David, To Come to the Land: Immigration and Settlement in Sixteenth-Century Eretz-Israel (Tuscaloosa and London: University of Alabama Press, 1999), 138-39 and 223; Ben-Sasson, "The Reformation," 260 - 69; Robinson, "Two Letters," 403-22; and Scholem, "Perakim," 242-48. See also introduction to an edition of Ha-Levi's writings, Abraham Ha-Levi, Maamar meshare kitrin, eds. Gershom Scholem and Malachi Beit-Arié (Jerusalem: Jewish National and University Library Press, 1978).

16 Ben-Sasson, "The Reformation in Contemporary Jewish Eyes," 266.

17 Divrey ha-yamim was divided into three parts. I and II were published together in Sabbioneta in 1554. From the third part only half has been published, ed. D. A. Gross (Jerusalem: Mosad Bialik, 1955). The entire part is preserved in two Mss., housed in the British Library: Or. 3656, Or. 10387. Currently, Robert Bonfil is preparing a critical edition. On the life and intellectual activity of Joseph Ha-Kohen see Martin Jacobs, “Joseph ha-Kohen, Paolo Giovio, and Sixteenth- 
the saints as before."18 Even remote observers like Abraham Ibn Migash (active in the second half of the sixteenth century), ${ }^{19}$ who settled in Constantinople and served as personal physician to Sultan Suleiman the Magnificent, was impressed with this position on images: "This congregation has cast off all faith in icons and priests and has discarded the form of this worthless creed [of Catholicism]."20

Luther's followers, among them "the most important princes and burghers in Germany," rejected papal authority, the adoration of the Virgin Mary and the saints, some religious festivities and fasts, and celibacy; "so their religion resolved itself into two religions to this very day," recapitulates Ha-Kohen. ${ }^{21}$ Later, the author of the Anonymous Prague Chronicle ${ }^{22}$ summarized the new religious customs:

A priest named Martinus Luther created turmoil in the Catholic religion, deriding and repudiating its customs. At the same time, the peasants rose up against the priests, seeking to expel them, and the priests were much afraid. There were others among the clergy who sympathized with Luther, despising their dogmas. Subsequently they agreed that priests could marry, that meat could be eaten on Fridays, that certain holy days should be abolished, that the Eucharist is false, and that crucifixes have no substance. ${ }^{23}$

Century Historiography,” in Cultural Intermediaries: Jewish Intellectuals in Early Modern Italy, eds. David Ruderman and Giuseppe Veltri (Philadelphia: University of Pennsylvania Press, 2004), 67-85; Yosef Haim Yerushalmi, Zakhor: Jewish History and Jewish Memory (Seattle: University of Washington Press, 1983), 460 - 81; Abraham David, "Igrono shel Josef ha-Kohen baal Emek ha-bakha," Italia 5 (1985): 7-105.

18 Ha-Kohen, Divrey, vol. II, 262v.

19 On Abraham Ibn Migash, see Encyclopedia Judaica (New York: MacMillan, 1971-1972), vol. 6, 95 and vol. 14, 21. He came from a dynasty of physicians; his father Isaac Migash or Megas was mentioned in a list of court physicians from 1548-1549, see Uriel Heyd, "Moses Hamon: Chief Jewish Physician to Sultan Suleiman the Magnifiecent," Oriens 16 (1963): 158. The philosophical-religious treatise Kevod Elohim is the only extant of his numerous works; it was published in Constantinople in 1585-1586, and reprinted by Ben-Sasson in Jerusalem in 1977, Abraham Ibn Migash, Kevod Elohim, ed. Haim Hillel Ben-Sasson (Jerusalem: Jewish National and University Library Press, 1977). See also Shaul Regev, "Secular and Jewish Studies among Jewish Scholars of the Ottoman Empire in the Sixteenth Century," in Frontiers of Ottoman Studies, eds. Colin Imber and Keiko Kiyotaki (London and New York: I. B. Tauris, 2005), 241-250; and Friedman, "The Reformation in Alien Eyes," 23-40, esp. 27.

20 Ibn Migash, Kevod Elohim, 127v.

21 Ha-Kohen, Divrey, vol. I, 150v.

22 A Hebrew Chronicle from Prague, c. 1615, ed. Abraham David, Engl. trans. Leon J. Weinberger and Dena Ordan (Tuscaloosa and London: University of Alabama Press, 1993).

23 Ibid., 28-29. 
Both Gans and the Prague Chronicle author, together with many others, remarked on the violent character of the religious struggle. Luther's teaching divided not only the "hearts of Christians" but also their lands and dominion. The chronicler of French history, Joseph ben Joshua Ha-Kohen, ${ }^{24}$ who held a rather favorable view of the Reformation and strong anti-Catholic sentiment, observed: "Thus, Martin grew wise, probing and investigating and amending many works and matters concerning their faith and cause, and discredited papal practices throughout Germany."25

Some Jewish texts distinguished sharply between Martin Luther's initial view on Jews and Judaism and the fierce anti-Semitic tone of his later writings. ${ }^{26}$ An anonymous Hebrew anti-Lutheran polemic portrays this turn as follows:

In the year 280 according to the small counting (1520), a priest named Martin arose and his name proves that he is a bitter material for Jews. ${ }^{27}$ He attracted dukes, lords and noblemen $^{28}$ from among his people, and scholars from his faith. He and his faction said that

24 He was born in Avignon, the papal enclave; however he descended from a family of expellees from Spain. He spent most of his life in Genoa. Encyclopedia Judaica vol 11, 595 and vol. 10, $241-42$.

25 Ha-Kohen, Divrey, vol. I, 104v. English translation according to Friedman, "The Reformation in Alien Eyes," 30.

26 Literature on Luther's attitude to Jews and Judaism is vast, e.g. Kaufmann, Luther's Jews; idem., "Luther and the Jews," in Jews, Judaism, and the Reformation in the Sixteenth-Century Germany, eds. Dean Phillip Bell and Stephen G. Burnett (Leiden and Boston, 2006), 69-104; Martin Stöhr, "Martin Luther und die Juden," in Die Juden und Martin Luther. Martin Luther und die Juden: Geschichte, Wirkungsgeschichte, Herausforderung, eds. Heinz Kremers, Leonore Siegele-Wenschkewitz and Bertold Klappert (Neukirchen: Neukirchener Verlag, 1985); Heiko Oberman, "Three Sixteenth-Century Attitudes to Judaism: Reuchlin, Erasmus and Luther," in Jewish Thought in the Sixteenth Century, ed. Bernard Dov Cooperman (Cambridge, Mass., and London: Harvard University Press, 1983), 326-64; idem., "Luthers Stellung zu den Juden: Ahnen und Geahndete," in Leben und Werk Martin Luthers von 1526 bis 1546, ed. Helmar Junghans (Berlin: Evangelische Verlag, 1985), 519-30 and 894-904; Robert Michael, Holy Hatred: Christianity, Antisemitism, and the Holocaust (New York: Palgrave Macmillan, 2006); Mark U. Edwards, Luther's Last Battles: Politics and Polemics, 1531-46 (Ithaca and New York: Cornell University Press, 1983); and Gordon Rupp, Martin Luther and the Jews (London: The Council of Christians and Jews, 1972).

27 A word play on the word komer (priest, monk), the name Martin and the phrase "khomer mar le-yisrael" meaning "bitter material for Jews." Also a word play on Martina, when combination of "mar" (bitter) and Aramaic word "tina” (clay, mud) repeats the meaning. Abraham David translates the phrase: "and his name proves that he is common clay"; A Hebrew Chronicle, 129. 28 "Pricim" may denote both noble men and violent men. Kaplan translates as "law-breakers"; Debra Kaplan, "Sharing Conversations: A Jewish Polemic against Martin Luther," Archiv für Reformationsgeschichte 103 (2012), 48. It is also a term used in some Hebrew version of Toledot Yeshu to denote Jesus' followers. 
[one should] not place a heavy burden on the Jews, and that [one should] treat them in a respectful and loving manner in order to attract them. And he brought proof and composed a book 'Jesus from the family of Hebrews'. ${ }^{29}$ And they mocked him, [saying] that he was a little bit like a Jew, and he regretted it. In order to divert suspicion, since they were complaining about him and saying that his faith tended towards Judaism, when he heard all of this, he changed his words, and wrote to all the nations to act badly towards them [the Jews]. And he said that he did what he had done previously only to draw them [the Jews] to his [Protestant] faith, but once he saw that they did not turn to him, and they were stiff-necked, and did not listen to him, he wrote libels about them, fulfilling the Scripture "he that uttered a slander is a fool" (Prov. 10:18). All sorts of false accusations and lies he could find he put into books, and he gave them [the Jews] a name, calling them Sabbatarians, which comes from the word Sabbath, meaning that they observed Sabbath. ${ }^{30}$

Accusations of Judaizing were hurled from the Catholics to the Reformed and back again. Luther himself was labelled 'semi-Judaeus' by ecclesiastical authorities. For his part, Luther criticized the sect of Sabbatarians in his book, Against the Sabbatarians (Wider die Sabbather), written in 1538. The Jewish author of the above-cited passage was clearly familiar with at least some of the content of Luther's treatise That Jesus Christ Was Born a Jew (Dass Jesus Christus ein geborener Jude sei), ${ }^{31}$ written in 1523 . Furthermore, he was able to grasp the turn in Luther's attitude toward Jews. In the early phase of his career - until around 1536, the reformer voiced concern over their precarious situation in Europe and enthusiastically greeted the prospect of converting them to reformed Christianity. ${ }^{32}$ Finding himself unsuccessful in that endeavor, he soon became a strong opponent of Judaism, and in his later career called for the harsh persecution of its adherents. Luther's later books, On the Jews and Their Lies (Von den Juden und ihren Lügen) and On the Holy Name and the Lineage of Christ (Vom Schem Hamphoras und vom Geschlecht Christi), constitute a treasury of anti-Semitic arguments, and he personally campaigned against the Jews in Saxony, Brandenburg, and Silesia. An outstanding example of his success in this effort is the mandate that Luther's prince, Elector of Saxony John Frederick, issued in 1536, prohibiting

29 Meaning the tract That Jesus Christ Was Born a Jew.

30 MS Mich. 121 (Bodleian), 270v. Versions of this paragraph were published in Ben-Sasson, "The Reformation in Contemporary Jewish Eyes," 289; concerning this MS see Kaplan, "Sharing Conversations," 41-63.

31 Martin Luther, Luther's Works, trans. Walther I. Brandt, vol. 45 (Philadelphia: Fortress Press, 1900 -1986), 195-229. Against the Sabbatarians may be found in Luther, Luther's Works, trans. Martin H. Bertram, vol. 47, 64-98.

32 See Ernst L. Ehrlich, "Luther und die Juden," in Antisemitism: Von der Judenfeindschaft zum Holocaust, eds. Herbert A. Strauss and Norbert Kampe (Frankfurt am Main: Campus, 1988), 47-65, here 50. 
Jews from inhabiting, engaging in business in, or passing through his realm. In his account of the expulsion of Jews from the city of Braunschweig in 1546, Eliezer Eilburg ${ }^{33}$ depicted a particularly adverse impact of Lutheran persecution:

We were all suddenly expelled [...] on the advice of the foul priest vile Mart[in] and other heretical scoundrels, and due to our iniquities, those prince[s] came before the Council of Braunschweig of accursed memory causing the expulsion with their libellous accusations and temptations. They annulled and broke our charter of many days and years which our fathers bought from them, and even though we had recently renewed our privileges for a great fortune, they did not honour them. ${ }^{34}$

The writings of Josel of Rosheim disclose Luther's increasing malice towards the Jews. ${ }^{35}$ Josel served as a representative of German Jewry during the reign of the emperors Maximilian I and Charles V, and he, along with his German-Jewish brethren, were directly exposed to the turmoil of the Lutheran Reformation. Unlike those living in the safety of foreign shores, they did not have the luxury of a distant view of the conflict. Jerome Friedman has characterized their approach to Luther and Lutheranism as non-ideological and pragmatic, expressing a "political position predicated upon concerns removed from esoteric messianism or other conceptual approaches." 36

Josel met Luther on several occasions, knew Martin Bucer (1491-1551), and was close with Wolfgang Capito (c. 1478-1541). In 1530, in the presence of the emperor and his court at the Imperial Diet in Augsburg, Josel had a public disputation with the baptized Jew Antonius Margaritha (1492-1542), who had published a pamphlet, The Whole Jewish Faith (Der gantze Jüdisch Glaub), ${ }^{37}$ full of

33 For a brief biography of the author, see Joseph Davis, "The Ten Questions of Eliezer Eilburg and the Problem of Jewish Unbelief in the $16^{\text {th }}$ Century," Jewish Quarterly Review 41, $3-4$ (2001): 293-336, esp. 295-300.

34 The text is part of the author's introduction to his work Machberet ha-measef, extant only in manuscript (located in New York, Jewish Theological Seminary, Mic. 2324). English translation according to David, "The Lutheran Reformation," 128-129. For a slightly different version of this paragraph, see Ben-Sasson, “The Reformation in Contemporary Jewish Eyes,” 289.

35 For the biographical survey of the German rabbi, see Marcus Lehmann, Rabbi Joselmann von Rosheim (Frankfurt am Main: Verlag H. Bergman, 1879); Ludwig Feilchenfeld, Rabbi Josel von Rosheim: Ein Beitrag zur Geschichte der Deutschen Juden im Reformationszeitalter (Strasburg: J. H. E. Heitz, 1898); Stern, Josel of Rosheim; Fraenkel-Goldschmidt, The Historical Writings. 36 Friedman, "The Reformation in Alien Eyes," 26, and 34-40 for further details.

37 Concerning Margaritha's text see Maria Diemling, "Anthonius Margaritha on the Whole Jewish Faith: A Sixteenth-Century Convert from Judaism and his Depiction of the Jewish Religion," in Jews, Judaism, and the Reformation in the Sixteenth-Century Germany, eds. Dean Phillip Bell and Stephen G. Burnett (Leiden and Boston, 2006), 303-334; Stephen G. Burnett, "Luther's Chief Witness: Anthonius Margaritha's Der ganz jüdisch Glaub (1530/1531),” in Revealing the Se- 
libelous accusations against Judaism. The disputation terminated in a decided victory for Josel, who obtained Margaritha's expulsion from the realm. ${ }^{38}$ Josel of Rosheim intervened on behalf of various Jewish communities throughout the Holy Roman Empire and he substantially improved their legal status due to the favorable attitude of Charles V - whom he even described as God's angel sent to protect Jews from the Lutherans:

\begin{abstract}
We have now beheld it with our own eyes. A nation which founded a new faith with all sorts of modifications attempted to cast off every yoke and plotted to attack us and destroy the Jewish nation by many oppressive decrees and abuses so that it might cease to be a people. He [God] sent his angels in the persons of compassionate kings who gave power and strength to the Emperor Charles to defeat the enemies over and over again, to frustrate their alliances and conspiracies, to subdue them, and to conquer their cities and provinces without effort. He [Charles] won the battle in a miraculous manner and saved the Jewish nation from the might of this new faith which had been founded by a monk called Martin Luther, who is impure, and who planned to wipe out all the Jews, young and old, and to slay them. ${ }^{39}$
\end{abstract}

Returning to our earlier polemical fragment, we note a striking reference to the Jews as "Sabbatarians." This mention indicates that the author's familiarity with - or understanding of - the tract Against the Sabbatarians ${ }^{40}$ was, at best, incomplete. Although Against the Sabbatarians was largely dedicated to anti-Jewish polemic, what prompted Luther to write it was his concern with the Sabbatarians, Christians who observed the day of rest on Saturday rather than on Sunday. In the work, Luther clearly distinguished between the Sabbatarians and Jews, whom he blamed for this Christian practice.

Despite the partiality in his comprehension of Luther's writings and various reformation movements' theologies, the author of the aforementioned fragment

crets of the Jews: Johannes Pfefferkorn and Christian Writings about Jewish Life and Literature in Early Modern Europe, eds. Jonathan Adams and Cornelia He $\beta$ (Berlin and Boston: De Gruyter, 2016), 183-200; Idem, "Distorted Mirrors: Anthonius Margaritha, Johann Buxtorf der Ältere and Christian Ethnographies of the Jews," Sixteenth Century Journal 25 (1994): 275 - 87.

38 Despite this decision, this work would be repeatedly reprinted and cited by anti-Semites over the coming centuries. Martin Luther read The Whole Jewish Faith in 1539 before writing his own anti-Semitic tract On the Jews and Their Lies in 1543. Josel himself acknowledged the fact that Luther was inspired by Margaritha in a letter to the Strasbourg city council; see Fraenkel-Goldschmidt, The Historical Writings, 388. For Josel of Rosheim's controversy with Margaritha see Elisheva Carlebach, "Jewish Responses to Christianity in Reformation Germany," in Jews, Judaism, and the Reformation in Sixteenth-Century Germany, 451-80, esp. 455 and 460-61.

39 Stern, Josel of Rosheim, 223-24.

40 Luther, Luther's Works, vol. 47, 89-92 and 94-95. 
demonstrates an impressive awareness of detailed distinctions within them. Debra Kaplan has rightly noted that it is likely that he had acquired this knowledge either orally or from a pamphlet detailing Luther's teachings, given what we know about the spread of the Reformation among Christians living in the Empire. Not only were Luther's works printed in pamphlet form in the vernacular to facilitate their circulation among laity, but digests of his writings were also published with great success. ${ }^{41}$ These were also read aloud to those who were illiterate, diffusing Luther's teaching beyond those who could read. ${ }^{42}$ It is thus likely that the Jewish author had either read such a text, or heard about it from a Christian neighbor who had read or heard these pamphlets..$^{43}$

Our polemical fragment may attest to continuous contact between Christians and Jews living in Europe from medieval times to the early modern period, including both formal and imposed interaction, and informal and voluntary encounters which could have occurred on an everyday basis. Moreover, not only elite authors debated religion; lay people were well acquainted with one another's teachings and rituals. ${ }^{44}$ The fact of informal conversations about religion intensified the motivation to compose polemical literature, especially that which was accessible to non-elite Jews:

And sometimes, the tricksters wish to argue with us about matters of faith, and in order to protect ourselves, for the law requires that we remain steadfast in our faith, I composed this, and it is not lengthy, and its language is clear, so that everyone who comes to read it can understand it, a youth and a small child can lead them (Is 11:6), all who understand the holy tongue. ${ }^{45}$

41 See, for example, Louise W. Holborn, "Printing and the Growth of a Protestant Movement in Germany from 1517-1524,” Church History 11, 2 (1942): 123-37; Richard G. Cole, "Reformation Printers: Unsung Heroes," Sixteenth Century Journal 15, 3 (1984): 327-39.

42 See, for example, Miriam Usher Chrisman, Lay Culture. Learned Culture. Books and Social change in Strasbourgh, 1480 - 1599 (New Haven: Yale University Press, 1982); Robert W. Scribner, For Sake of Simple Folk: Popular Propaganda for the German Propaganda (Oxford: Claredon Press, 1994).

43 Kaplan, "Sharing Conversations," 51.

44 For medieval times see Israel Jacob Yuval, Two nations in Your Womb: Perceptions of Jews and Christians in Late Antiquity and the Middle Ages, trans. Barbara Harshav and Jonathan Chipman (Berkeley, Los Angeles and London: University of California Press, 2006); Ivan G. Marcus, "A Jewish-Christian Symbiosis: the Culture of early Ashkenaz," in Cultures of the Jews: A New History, ed. David Biale (New York: Schocken Books, 2006), 449-516; and Jonathan Elukin, Living Together, Living Apart: Rethinking Jewish-Christian Relations in the Middle Ages (Princeton: Princeton University Press, 2007).

45 Ms 121, 173r. English translation according to Kaplan, "Sharing Conversations," 48. 
The polemicist here defined the new threat that Lutheranism posed to Jews, that is, the emphasis on Sola scriptura, the centrality of the Scripture in the creed of Martin Luther: "Their faith is based on our prophets and holy writings, and if we did not have prophets, then they would have no proof or anything to say."46 The anonymous Jewish polemicist even warned his readers to refrain from discussing biblical verses while in conversation with Lutherans:

And at first, do not begin and talk to them [using references] from the Torah, the Prophets and the Writings. And it is only through the way of nature, and with heart and mind, that one should believe. For it is apparent that there is a unity governing the entire world, ruling over below and above. And this is what you must do to purify and cleanse them, speak to them as if there were no book in the world..$^{47}$

It seems that neighborly discussions about faith, then, may have prompted the composition of the polemic. Interestingly, the author did not instruct his readers to cease speaking with their neighbors. Rather, he recommended that in these conversations Jews avoid discussing the Bible, and instead, that they focus on demonstrating the rational nature of Judaism. In this vein, we may recall an earlier Ashkenazi polemicist, Yom Tov Lipmann Mülhausen (d. 1421), who also defined the necessity to develop rationally and philosophically oriented arguments and thus to equip Jews with more sophistic resources to hold their own in the face of the increasingly sophisticated polemical tools of the rival faith. ${ }^{48}$

The anonymous author of our anti-Lutheran polemic sensed the seductiveness of the Lutheran idea of Sola scriptura; the next author we shall consider, this time a representative of Italian Jewry, scrutinized the problematic idea of Sola fide, justification by faith alone. Several passages in Offering of Zeal (Minhat kenaot), an acerbic polemic against Jewish Aristotelianism ${ }^{49}$ written by Yehiel Nissim (Vitale) ben Samuel of Pisa $^{50}$ (c. 1493- before 1572), deal with the differ-

\footnotetext{
46 Ibid., 57.

47 Ibid.

48 Ora Limor and Israel Jacob Yuval, "Scepticism and Conversion: Jews, Christians, and Doubters in Sefer ha-Nizzahon," in Hebraica Veritas? Christian Hebraists and the Study of Judaism in Early Modern Europe, eds. Alison Coudert and Jeffrey S. Shoulson (Philadelphia: University of Pennsylvania Press, 2004), 159-79, esp. 175-76.

49 On this belated battle against philosophy and conflict with Azariah de' Rossi, see Israel Zinberg, A History of Jewish Literature: Italian Jewry in the Renaissance Era (Cincinnati and New York: Hebrew Union College Press and Ktav Publishing House, 1974), 89-95.

50 On him, see Alessandro Guetta, Italian Jewry in the Early Modern Era: Essays in Intellectual History (Boston: Academic Studies Press, 2014), 12-28; Bonfil, Rabbis and Jewish Communities in Renaissance Italy (Oxford: Oxford University Press, 1990), esp. 284-89 and 292-93.
} 
ence between Protestants and Catholics in respect to predestination and free will:

[Fundamental] is the principle of free choice [...] as opposed to the mockers who claim that man neither prospers nor suffers perdition by his works unless divine sanction has so determined... In our generation we have seen the sages of the gentiles divided into sects... Some maintain this view [that man neither prospers nor suffers perdition by his works unless divine sanction has so determined] which is more bitter than wormwood and destructive to the very foundations of faith. But others maintain the principle of free will in a simple and straightforward manner, branding their coreligionists as heretics and apostates $\left[\ldots . . .^{51}\right.$

Yehiel rejected the fideistic position opposing belief in free will and the merit of good deeds, doctrines which were held up as common to Judaism and the Catholic Church.

The new sect that has emerged among Christians who fail to understand the meaning of Scripture, may their souls be damned. In their opinion all the actions of man are of necessity subject to God's determination in the absence of which man can do neither good nor bad. The same is also the case with punishment $\left[\ldots . . .^{52}\right.$

At this point, we will leave aside specific examples of doctrinal issues and turn to the next theme which preoccupied the majority of Jewish authors reflecting upon the religious battle within Western Christendom. Reformation ferment had brought about religious uncertainty. Not everyone, however, understood in a negative light the religious chaos and even violence of those times, when "Edom turned against Edom." 53 Abraham Ibn Migash, for example, saw in the formlessness of doctrinal opinion a chance to attract Gentiles to Judaism and thus realize the next step towards the Messianic redemption:

God has aroused the spirit of the Lutherans - who originally belonged to them, but now rejected their views [...]. So they abrogated and devastated much of the unworthy faith they possessed. And each day passes, this people is gaining in strength, so that it waxes exceedingly great - 'And the Lord shall be King over the earth' (Zech. 14:9).

Now behold, this congregation has cast off all faith in icons and priests, and has discarded the form of this worthless creed. So their faith has reverted to a state of primeval

51 Yehiel of Pisa, Minhat kenaot, ed. David Kaufmann (Jerusalem: Mekitze nirdamim, 1970), 11. English translation according to Friedman, "The Reformation in Alien Eyes," 27-28.

52 Yehiel of Pisa, Minhat kenaot, 46. English translation according to Friedman, "The Reformation in Alien Eyes," 28. See also Ben-Sasson, "The Reformation in Contemporary Jewish Eyes," 294.

53 An Expression from A Hebrew Chronicle, 55. 
flux. Where there are a thousand of them one cannot find ten men willing to rely upon a single doctrine or consent to a given line of reasoning. Thus they are in a state of formlessness, ready to take shape, since faith has departed and no longer finds expression in their utterances. But they have been made ready to assume form when they will find favour with God, after being scourged for their sins and the sins of their fathers, for all that they and their fathers have perpetrated against Israel. And when they find favour with God they will be ready to accept the faith. ${ }^{54}$

Disunity and non-dogmatism, "the return to the state of primeval flux," as Ibn Migash called it, could be perceived positively as well as negatively. In his view, the reformation movement that had originated in the midst of Christianity was an instrument of God's will, designed to destroy the old Christianity which was now afflicted by internal fragmentation. The Lutheran rejection of traditional Catholic beliefs, especially the veneration of saints and images, indeed seemed destined to bring the Gentiles closer to the true monotheism.

In his Works of God (Maase ha-Shem), a commentary on the Pentateuch, Eliezer Ashkenazi (1513-1585) ${ }^{55}$ expressed an optimistic view of the dynamic changes and voiced sanguine expectations stemming from the prevailing religious nonconformity. Ashkenazi, who lived an itinerant life - residing in Salonika, Egypt, Italy, Prague and Poland - interpreted "Dor Babel” - the generation of dispersion ("Dor ha-haflagah") - as mirroring the times he lived in. ${ }^{56}$ Among those Jewish authors who reflected the Christian Reformation in their writings, both Ashkenazi and Ibn Migash evaluated religious pluralism positively, demonstrating a divine design. For them, pluralism was a sign of the absence of intellectual and religious repression and a necessary prerequisite for the free performance of religious inquiry.

We have seen that the Jews appraised the Reformation not only as an historical event, but also as an act in apocalyptic history. The Lutheran schism appeared at a time when Jews were in particular need of encouragement. Let us recall that in 1517, a mere generation after the expulsion from Spain and forced

54 Ibn Migash, Kevod Elohim, 127v-128r. For a shortened version, see Ben-Sasson, “The Reformation in Contemporary Jewish Eyes," appendix I.

55 Little has been written about this thinker and his work. For scattered references, see BenSasson, Hagut ve-hanhagah (Jerusalem: Mosad Bialik, 1959); and Byron L. Sherwin, Mystical Theology and Social Dissent (London: Littman Library of Jewish Civilization, 2006), 58-69, especially for his conflict with Yehudah ben Bezalel of Prague. The first and only comprehensive study of Ashkenazi is N. Ecker-Rozinger Universalistic Tendencies in Rabbi Eliezer Ashkenazi's Teachings [Hebrew] (Ph.D. dissertation, University of Haifa, 2010).

56 Byron L. Sherwin, “The Tower of Babel in Eliezer Ashkenazi’s Sefer maase ha-Shem,” Jewish Bible Quarterly 42, 2 (2014): 83-8. 
conversions in Portugal had elapsed. Hence, some Jews, especially the writers of Sephardi origin, perceived this phenomenon as retribution for the suffering brought upon them by the Catholic Church. Abraham Ibn Migash, fascinated by the fundamental rivalry between Edom and Edom, anticipated the ultimate collapse of Christianity and return to Judaism: "[...] they will find favor with God after being scourged for their sins and the sins of their fathers for all that they and their fathers have perpetrated against Israel." 57

Moreover, the idea emerged that the Lutherans were, in fact, Jews - or at least of Jewish lineage. Solomon Usque (c. 1500 -after 1555) ${ }^{58}$ in Consolation for Tribulations of Israel (Consolação ás Tribulações de Israel), from 1553, wrote in reference to forced conversions in Toulouse, in 5106/1346:

In this way that province was sown with this feed, and many of the descendants of these Jews are probably still uncomfortable in the faith which their ancestors accepted so reluctantly. It would not be implausible to assume that from these people stem the Lutherans, ${ }^{59}$ who have sprung up everywhere in Christendom. For since throughout Christendom Christians have forced Jews to change their religion, it seems to be divine retribution that the Jews should strike back with the weapons that were put into their hands; to punish those who compelled them to change their faith, and as a judgment upon the new faith, the Jews break out of the circle of Christian unity, and by such actions seek to re-enter the road of their faith, which they abandoned so long ago. ${ }^{60}$

A similar understanding of Luther as a double agent acting in favour of Jews and Judaism is found in the aforementioned Kevod Elohim of Abraham Ibn Migash. The third chapter of the third book contains various anti-Christian tales and remarks, among them, on folio 127a, a passage from the Toledot Yeshu narrative. Of particular relevance is the part following the death of Jesus when the land of Palestine witnessed persistent violence between Jesus' followers and adherents of Rabbinic Judaism. The story, representing a core of the so-called Acts narrative of Toledot Yeshu, depicted a wise and righteous scholar selected by the rabbis to save the purity of Judaism at the expense of living a life of pretense. Eliyahu, as the sage is named in the version quoted by Abraham Ibn Migash, pretended to be authorized by Jesus himself to teach his followers - "the lawless ones who

57 Ibn Migash, Kevod Elohim, 127v-128r.

58 Concerning Usque see Abraham A. Neumann, Samuel Usque. Marrano Historian of the $16^{\text {th }}$ Century, Landmarks and Goals (Philadelphia: Jewish Publication Society, 1953), 105-132; and Juan Berajano Guitierez, "Samuel Usque and the Consolation for the Tribulation of Israel," Halapid 21-22 (2011-2012): 34-66.

59 He used this name to denote all reformed groups.

60 Samuel Usque, Consolation for the Tribulations of Israel, trans. Martin A. Cohen (Philadelphia: Jewish Publication Society, 1965), 193. 
desecrate Shabbats and holy festivals and slay one another" as they were called by the rabbis - the new law and to separate them from the people of Israel. ${ }^{61}$

On the following page Ibn Migash adds his own experience, framing the story from Toledot Yeshu in a personal context:

One day, when I was in the royal courtyard, the Chamberlain, whose name was Mustafa Aga, said to me: 'Come, I will show you how you [Jews] destroyed human lives.' He brought one book from the royal collections and on reading it, I found that it stated that the Jews worked to destroy the Christian community,

writes Ibn Migash. The following narrative resembles that of Toledot Yeshu: the story of a Jewish sage who pretended to be a Christian in order to deceive Christians and divide them. Making contradictory statements to seventy priests regarding their faith, he thus split them into seventy sects. He then told them that in a few days he would ascend bodily to heaven. The method he employed both argues against the belief in Jesus' ascension to heaven and explains the testimony of the empty tomb using a motif from medicine without denying the possibility of the fact itself: the sage drowned himself in a barrel full of quicksilver, a substance which melted all his bones and flesh. The consequences were the following:

And they slashed one another according to their practice, with swords and spears, until they were covered in blood, because they quarrelled so much, for they were divided into many groups and the disputes multiplied. This destroyed their habitations, and there were strife and fighting in their tents [...] And I, too, have heard evil reports spread by many, for this matter [that the division in Christianity was induced by Jews] is known but kept secret among the gentiles [...] Be it as it may, it is consensus of opinion among all prophets that our people were the cause of it. ${ }^{62}$

Christians facing the hardships of the sixteenth-century religious wars were thus punished for the sins of their fathers who had persecuted the people of Israel throughout the history, just as Jesus's followers were led to confusion and eclipse

61 The quotation of Toledot Yeshu in Kevod Elohim is very similar to the version preserved in MS Strasbourg, one of the most known versions of Toledot Yeshu which, according to William Horbury, was written down in the seventeenth-century Galician Karaite milieu, however the identical text circulated earlier in France and Spain; see William Horbury, "The Strasbourg Text of the Toledot," in Toledot Yeshu ("The Life Story of Jesus") Revisited, eds. Peter Schäfer, Michael Meerson and Yaakov Deutsch (Tübingen: Mohr Siebeck, 2011), 49-59, esp. 55.

62 Ibn Migash, Kevod Elohim, 127v-128r; translation according to Ben-Sasson, "The Reformation in Contemporary Jewish Eyes," 85-87. 
by Eliyahu at the beginning of the Common Era. The passage ends with an abbreviated quotation from the Mishneh Torah, and Ibn Migash declared that:

Had this [the clash within Christianity] happened in the days of Maimonides [...] he would have danced ecstatically for sheer joy [...] for he has raised up from among them and within them, of their own flesh and bone, of their kin and religion, a phenomenon that destroys them [...] it incites them, fraction against fraction, to destroy their faith; and they burn the statues of their gods in fire, and their asherot they cut down, and their icons they break in pieces [...] This He does unto them by means of leaders and their friends, their brethren Lutherans. For the sword of every man is against his brother, and each man is against his friend and his relative, against his son and his brother, city against city, kingdom against kingdom. ${ }^{63}$

Clearly, then, Ibn Migash adopted the idea of Jewish responsibility for developments within Christian religion. Like Eliyahu - the righteous and learned Jew sent by the rabbis to take charge of the Christian hierarchy and institute new rules in the Toledot Yeshu Act narrative - Martin Luther in Ibn Migash's reading is a counter-character: a man who, from within Christian circles, works to bring conflict and collapse to Christianity.

Our Jewish authors were aware that the Catholics charged Luther with the heresy of Judaizing. After all, they themselves perceived some aspects of the new religion as close to Judaism, the original, true, and pure belief. When Gershom Scholem summarized Abraham ben Eliezer's view of Luther, he even used words like "crypto-Jew, a proselyte whose revolt was not limited to the pope but extended to Christianity as a whole, so as gradually to draw the gentiles near to the Jewish religion and its laws." ${ }^{4}$ Passages from Kevod Elohim stress Lutheran iconoclasm, and also for other Jewish thinkers dealing with the Reformation the rejection of images and the veneration of saints represented the first thing they noticed about the new Christian sect. Ibn Migash goes one step further in his presentation of Luther - the one who ignited a conflagration within Christianity - as part of God's plan working in favor of the congregation of Israel.

The above-discussed selection of Jewish texts does not offer a systematic view of the German Reformation, both because no unified Jewish assessment of this development in Christian history ever emerged and because the Reformation itself manifested in various forms. Jewish historiographic works of the early modern period treated the Reformation as an external event, often assessing it in a brief and dispassionate manner. Following a short period of curiosity and cau-

63 Ibn Migash, Kevod Elohim, 128r.

64 Scholem,"Perakim," 161. 
tious hope, Jewish authors living in the area of the Holy Roman Empire reacted to the changing political realities and novel religious forms with a bitter grasp of the negative ramifications of Luther's activities. In Germany, Luther was unequivocally "impure," one who "sought to destroy and to kill all of the Jews, both young and old" - the newest embodiment of the archetypal villain Haman. ${ }^{65}$ Texts written by authors living beyond the areas directly affected by Luther's policy, by contrast, display a significantly more creative approach to the Reformation. The scholarship on the Christian uses of Jewish history, Jewish literature, and Jewish figures for internal needs, be they theological, sociological, or political, is vast. It ought to come as little surprise, then, that the Jews engaged in similar exploits of expropriation.

65 As expressed by Josel of Rosheim in Sefer ha-Miknah; compare Ben-Sasson, "The Reformation in Contemporary Jewish Eyes,” 272 and 288. 
